UDC 377/378.09:74/75(477)"18/193"'

DOI https://doi.org/10.32840/1992-5786.2020.71-1.2

M. A. Boichenko

Doctor of Pedagogical Sciences, Associate Professor,

Associate Professor at the Department of Pedagogy

Sumy State Pedagogical University named after A. S. Makarenko

A. M. Nykyforov

Candidate of Pedagogical Sciences,

Sculptor, Self-employed

\title{
RESEARCH OF THE LIFE AND CREATIVE PATH OF THE UKRAINIAN ACADEMY OF ARTS' FOUNDERS BY MODERN SCIENTISTS: PEDAGOGICAL ESSAY
}

The article is devoted to the state of research of life and creativity of the founders of the first higher art school in Ukraine in the works of modern scientists. The aim of the article is to study the contribution of artists-teachers the founders of the first Ukrainian Academy of Arts in the formation and development of national art education in Ukraine in the early XX century, covered in modern scientific research. It is found out that on December 18, 1917, on the initiative of the creative elite of Kyiv, with the support of the Central Rada and personally the Chairman of the Central Rada M. Hrushevskyi, the Ukrainian Academy of Arts was established.

It is revealed that the teaching staff of the newly established institution of higher art education included leading artists, namely: M. Boichuk, M. Burachek, M. Zhuk, V. Krychevskyi, F. Krychevskyi, A. Manevych, O. Murashko, H. Narbut.

It is stated that the first elected rector of the Ukrainian Academy of Arts was Vasyl Hryhorovych Krychevskyi (1873-1952), who taught such disciplines as: "Folk Art", "Ornament", "Architecture", "Composition'. It is noted that the current rector of the academy (1917-1919) was Fedir Hryhorovych Krychevskyi (1896-1947), who headed the easel painting workshop. It is established that Heorhii Ivanovych Narbut (1886-1920) was appointed the head of the graphic workshop; Mykhailo Lvovych Boichuk (1882-1937) taught the disciplines "Fresco" and "Mosaic"; Oleksandr Oleksandrovych Murashko (1875-1919) was the head of the training workshop of the course "Genre Painting"; Mykola Hryhorovych Burachek (1871-1942) and Abram Anshelovych Manevych (1881-1942) taught the discipline "Landscape"; Mykhailo Ivanovych Zhuk (1883-1964) headed the studio of portrait painting.

It is shown that creative and pedagogical activity of the founders of the higher art school of Ukraine was based on the research and the use of traditional Ukrainian art elements in combination with the latest European trends in the development of art and education.

It is concluded that the Ukrainian Academy of Arts, founded in 1917, enabled Ukrainian artists to obtain professional art education at home, provided a high level of professional training of artistic staff and laid the foundations for the development of domestic pedagogy in the field of fine arts.

Key words: formation of higher art education in Ukraine, founders of the first Ukrainian Academy of Arts.

Introduction. Art education in the early XX century was marked by creation of the first Ukrainian Academy of Arts on the basis of vocational art schools in Kyiv, Kharkiv, Odessa and Lviv, in which much attention was focused on solving the problems of training artistic-pedagogical staff. Of particular interest to scholars is the specified period in modern conditions of improving and reforming the system of national education, an organic component of which is art education.

Analysis of recent research and publications. The problem of establishment of the Ukrainian Academy of Arts attracted researchers' attention in the Soviet period, at the same time, at early $\mathrm{XXI}$ century the scientists do not miss it, as evidenced by numerous investigations of historians, teachers, culturologists, philosophers, art critics. In particular, the pedagogical component of this issue is covered in the publications of O. Kovalchuk, L. Rusakova; I. Ushakova considered in her articles the aesthetic principles in the circle of the outlined problem; from the standpoint of culturology studied this topic V. Ruban-Kravchenko; R. Shmahalo investigated the problem from a pedagogical and art point of view at the same time. In particular, in the pages of his scientific research, the author rightly argues that the study of the history of art education is a separate and no less important part of art history than the study of styles and "figurative visions". V. Starchenko defended the priority influence of folk art on the work of professional artists of Ukraine in the second half of the XIX - early XX century. An important aspect in revealing the peculiarities of art education development in Ukraine in the early XX century is 
the study of the contribution of artists-teachers the founders of the first Ukrainian Academy of Arts in the vector of historical and pedagogical science.

The aim of the article is to identify the state of research of the life and creative path of the founders of the Higher Art School of Ukraine in the explorations of modern scientists.

Research results. The study of literary sources, in particular the structural analysis of O. KashubaVolvach's work, has shown that in July 1917 the creative elite of Kyiv initiated creation of the Academy of Arts in Ukraine, which would lay the foundations for the latest domestic pedagogy in the field of fine arts. The chairman of the Central Council M. Hrushevskyi supported this idea [1]. It is important to note that in August 1917 the charter of the education institution was developed, and the teaching staff was determined, which included such artists as: M. Boichuk, M. Burachek, M. Zhuk, V. Krychevskyi, F. Krychevskyi, A. Manevych, O. Murashko, H. Narbut. On December 18 of the same year, the Ukrainian Academy of Arts was established [2]. According to R. Shmahalo, the new education institution with the above-mentioned teaching staff and a small contingent of students was similar to foreign free academies [3]. Despite the fact that the academy had a limited number of disciplines (painting and graphics), in a short period of time the founders of the academy managed to educate a pleiad of artists and artiststeachers who made a significant contribution to the formation of national art education aimed at establishing art school on the basis of national traditions and culture. According to L. Rusakova's study, implementation of such a topical idea had become a matter of state importance [4]. Thus, with establishment of the academy for Ukrainian artists, they received an opportunity to get higher education not outside Ukraine, but in the homeland.

In the course of the research it was established that Heorhii Ivanovych Narbut (1886-1920) was chosen as the professor - the head of the graphic workshop, as the most outstanding Ukrainian graphic artist of the studied period.

S. Bilokin has found out that in $1917 \mathrm{H}$. Narbut moved to Kyiv and began to study traditional folk art in order to create his own Ukrainian style. To do this, Heorhii Ivanovych, who himself came from an ancient Cossack sergeant family, studied Cossack antiquities and Ukrainian urban medieval culture: Ukrainian old prints and ceremonial "parsuny" portraits (he borrowed for his art graphics from the ancient portrait not only the figure but also the ornament of the dress, its decorative, planar interpretation) [5].

A study of the literature has shown that $\mathrm{H}$. Narbut won the competition for the best sketch of Ukrainian paper money. In his sketch, the artist used images of Ukrainian Baroque ornaments of the XVII-XVIII centuries, decorative fonts and the sign of Prince Volodymyr's trident, which later became the state emblem of Ukraine. We consider it necessary to emphasize that (according to modern scientists) the main in the artist's creativity was the work on the graphic series "Ukrainian Alphabet", in fifteen sheets of which the artist demonstrated a variety of techniques that allowed in black and white graphic sheets to depict a large number of characters, to convey the beauty of Ukrainian nature. This work was recognized as a real masterpiece in the early XX century [6].

As it is noted by Soviet scientists, researchers of artistic-pedagogical and educational activities of the artist (P. Biletskyi, S. Bilokin, F. Ernst, V.Hrynevych, D. Horbachev, V.Zhadko, I.Krushelnytskyi, V.Sichynskyi,Ya.Steshenko,S.Chekhonin,P.Utevska), $\mathrm{H}$. Narbut "lived with the problems of the academy from creation of the press to financial issues - a young energetic professor did everything" [7]. By the way, during the difficult times of the civil war, in 1919, $\mathrm{H}$. Narbut was elected the rector of the academy. It is worth noting that when General Denikin's troops deprived the academy of its premises, the teacher placed educational art workshops in his own house.

Contemporary scholars, in particular S. Dudnyk, N. Kovpanenko, and V. Starchenko, continued to study the artist's contribution to the formation of the national art school. The study of these works allowed us to establish that having authority in artistic and cultural-educational circles, $\mathrm{H}$. Narbut in a short period of time managed to change his ideas about the art of graphics and methods of teaching, combining in his creative and pedagogical work traditional folk art of Ukraine and leading trends of Western European art. His works, published in books and periodicals, could be found in every home, and thus they became part of people's lives [9]. The samples of Ukrainian state paper money and bonds, postage stamps, change coins, the emblem of Kyiv, the emblem and the seal of the Ukrainian State created by $\mathrm{H}$. Narbut became an important milestone in the cultural and educational space of Ukraine in the early XX century.

It should be noted that the first rector of the Ukrainian Academy of Arts in Kyiv was elected Vasyl Hryhorovych Krychevsky (1873-1952), who taught such disciplines as: "Folk Art", "Ornament", "Architecture", "Composition". However, the first acting rector (1917-1919) was his younger brother Fedir Hryhorovych Krychevskyi (1896-1947), who headed the easel painting workshop at the academy.

The first researchers of the life and creative activity of artists-teachers of brothers Vasyl and Fedir Krychevskyi (V. Galaida, V. Voroniuk, O. Druh, D. Malakov, S. Tsalykh, P. Selihei, V. Pavlovskyi, B. Pevnyi, S. Tsalykh) have found out that in 1903 V. Krychevskyi received the first prize in the competition of the Poltava Zemstvo building 
project, which was later built according to his plans and became a model of a new architectural style (Ukrainian architectural modern), based on Ukrainian folk architecture. Information about Vasyl Krychevsky's creative activity was supplemented by modern scientists (N. Dmytrenko [10], O. Kovalchuk [11], V. Ruban-Kravchenko [12]), from whose studies it has become known that at the beginning of Vasyl Krychevsky's creative path he led carpet workshops of Khanenko's family in the village of Helenivka, Vasylkiv district, Kyiv province, and a ceramic school in Myrhorod (1912-1913). Later, the artist collaborated with Mykhailo Hrushevskyi (who in 1917-1918 was the chairman of the Central Council): he made covers for his books, consulted on historical issues. In addition, he kept his own archive in M. Hrushevskyi's house, which testifies to their friendly relations. Together with $\mathrm{H}$. Narbut he took part in a competition to create the heraldry of the Ukrainian People's Republic (developed the emblem, the seal, worked on the creation of banknotes, etc.). Vasyl Krychevskyi, who was the best Ukrainian graphic artist at the time, was commissioned to develop the state symbols of the newly formed Ukrainian People's Republic.

The analysis of the above-mentioned works has allowed to outline the artist's contribution to the formation of the national art school: in addition to painting, in which Vasyl Krychevskyi was a representative of "Ukrainian Impressionism", and graphics, where he associated modernity with decor and decoration of books of the XVII and XVIII centuries, art historians consider him a creator of the new Ukrainian style in architecture.

The younger brother Fedir Krychevskyi studied at the Moscow School of Painting, Sculpture and Architecture, later studied at the St. Petersburg Imperial Academy of Fine Arts, was on a business trip to Germany, Austria-Hungary, France and Italy. $\mathrm{He}$ received the title of an artist with the right to teach in secondary and higher education institutions. In 1913-1917 Fedir Hryhorovych was a teacher and director of the Kyiv Art School, subordinated to the Imperial Academy of Arts. It is important to note that in 1916 he was a member of a special commission to study the art schools of the Russian Empire in order to transform one of them into a higher education institution. Thus, at the time of opening of the Ukrainian Academy of Arts, Fedir Krychevskyi had experience in artistic, creative, exhibition, pedagogical, organizational, managerial work. Apparently, that is why his older brother Vasyl resigned as rector of the Ukrainian Academy in 1917 in favor of Fedir.

Mykhailo Lvovych Boichuk (1882-1937) was a Ukrainian monumental artist, the leader of the "Boichukist group", a member of the Taras Shevchenko Scientific Society since 1912, a professor of the Ukrainian Academy of Arts since 1917, where he taught the Fresco and Mosaic courses. Researchers of M. Boichuk's life and creative activity (S. Bilokin, O. Kovalchuk, O. Rypko, O. Yurchyshyn, O. Storchai, L. Sokoliuk, H. Mishchenko) claim that he studied: in the studio of Yu. Pankevych in Lviv, at the expense of Metropolitan Andrii Sheptytskyi, he studied at the Vienna Academy of Arts, and later at the Krakow and Munich academies. Then for a few years he went to Paris to study achievements of the world culture. Having received a thorough academic education, the artist delved into the primitive folk art [14].

As a result of the analysis of investigations by O. Kashuba-Volvach [15], O. Kovalchuk [16], N. Kovpanenko [17], L. Sokoliuk [18] it is established that in 1911-1912 Mykhailo Boichuk lived in Lviv, worked on monumental paintings, restored icons in the National Museum of Lviv, painted churches; from 1917 he worked in Kyiv, restored works in the collection of $\mathrm{V}$. Khanenko, developed a method of fixing frescoes in the baptistery of St. Sophia's Cathedral, in 1924 he opened frescoes in the Assumption Cathedral of the Yelets Monastery in Chernihiv. At the end of the 1925, the Association of Revolutionary Art of Ukraine (ARAU) was founded in Kyiv, uniting the Boichukists (M. Boichuk and his students and followers). ARAU promoted introduction of art in everyday life, combining it with life, denied naturalistic realism. The Boichukists aspired to the national identity of Ukrainian art. These ideological and artistic principles did not fit into the canonized framework of "Soviet art", in 1936 the People's Commissariat of Internal Affairs (PCIA) arrested M. Boichuk, and on July 13, 1937 he was shot in Kyiv.

Studying the works of modern scholars made it possible to outline the artist's contribution to the formation of the national art school: in his creative pursuits $\mathrm{M}$. Boichuk acted as a monumental innovator, who created his school of monumental painting on the basis of Ukrainian folk art, united students (like-minded and followers). It is worth noting that $\mathrm{M}$. Boichuk refused to participate in art exhibitions because he did not see the need for it, he believed that the appointment of monumental artists are public buildings and wide squares, where they are "exhibited" constantly. During the Soviet era, his monumental works were completely destroyed.

Oleksandr Oleksandrovych Murashko (1875-1919) - a Ukrainian painter, teacher and public figure, a nephew of Mykola Murashko (1844-1909), aUkrainian artistand teacher. He taught "Genre Painting" at the Ukrainian Academy. According to the researcher of O. Murashko's personality L. Chlenova, the artist began working in the stepfather's icon painting studio, later studied at his uncle's art school, graduated from the Art School at the St. Petersburg Academy of Arts in the class of I. Repin, improved his skills in Paris and Munich [19]. According to D. Dobriian [20], in 1904 the artist created the painting "Carousel", which 
was exhibited at the Munich International Exhibition in 1906, received a gold medal and brought O. Murashko world recognition. The artist received invitations from the capitals and cities of Europe: Berlin, Vienna, Paris, Amsterdam, Munich, Venice. However, in 1907 he returned to Kyiv. Without leaving active participation in the openings of the capital city, he began active artistic activity, and from 1917 - pedagogical work at the Ukrainian Academy of Arts. The artist's contribution to the formation of the national art school is that $O$. Murashko became the first artist-teacher in Ukraine, who in his work constantly turned to research and experimentation. Oleksandr Murashko's recognition became a recognition of not only an individual artist, but also of domestic fine arts in general. Thanks to O. Murashko, Ukrainian art emerged from a narrowly national, provincial state, and the artist's talent raised him to the Western European level, which was reflected in the artist's pedagogical activity.

One of the founders and teachers (19171921) of the Ukrainian Academy of Arts - Mykola Hryhorovych Burachek (1871-1942), a Ukrainian painter, writer, art critic, taught "Landscape" at the Ukrainian Academy. Researchers of the artist's life and creative activity (V. Ablitsov, A. Budkevych, Y. Diuzhenko, O. Zavalniuk, V. Matsko, L. Tkachova) have found out that M. Burachek studied at the Krakow Academy of Fine Arts, in 1910-1912 in Paris, he later worked in the studio of $A$. Matisse [21]. The contribution of the artist-teacher to the formation of the national art school is that in the best works the poetic nature of Ukraine is skillfully embodied and transmitted.

Abram Anshelovych Manevych (1881-1942), a Ukrainian, Belarusian and American modernist artist, who from 1917 taught "Landscape" at the Ukrainian Academy. According to O. Zhbankova's research, in 1913 a successful exhibition of A. Manevych's works took place in the Duran-Ruel Gallery in Paris; later, in 1917 he was invited to teach at the Ukrainian Academy [22].

A landscape artist Abram Manevych skillfully recreated images of Ukrainian nature. In his temperamentally painted canvases, life always "dynamically pulsates and at the same time the melody of barely perceptible sadness sounds", which testifies to the understanding of the deep essence of being. The philosophical approach of the artistteacher to professional activity significantly enriched the national art school.

Mykhailo Ivanovych Zhuk (1883-1964), a Ukrainian artist, professor of the Ukrainian Academy of Arts, later vice-rector of the Art Institute in Odessa, created more than twenty portraits of famous Ukrainian cultural figures, illustrated works by Ukrainian writers. He was fond of photography, wrote poetry and prose. He wrote memoirs about Lesia Ukrainka, Ivan Franko, and Mykhailo Kotsiubynskyi. He taught the discipline
"Portrait" at the Ukrainian Academy. The researcher of the artist's life and creative activity $O$. Lahutenko notes that Mykhailo Zhuk was engaged in the creation of bookplates, was fond of the art of silhouettes, made a great contribution to the formation of this genre in contemporary Ukrainian art [23]. Thus, under the guidance of the artist-teacher, an active study of folk art was started.

Conclusions. The analysis of the modern scientists' works on the contribution of the founders of the first Ukrainian Academy in the development of art education, suggests that the first institution of higher art education:

- provided a high level of professional training of artistic staff;

- provided an opportunity for Ukrainian artists to obtain professional art education at home;

- carried out the educational process on the basis of the use of elements of Ukrainian folk art in combination with progressive European art and educational trends.

The study makes it possible to conclude that the Ukrainian Academy of Arts, founded in 1917 through the activities of artists-teachers, founders of the academy, laid the foundations for the development of modern domestic pedagogy in the field of fine arts.

The analysis of archival materials on the coverage of pedagogical and cultural-educational activities of the founders of the Ukrainian Academy of Arts is the subject of further personalistic investigations in the field of historical and pedagogical science.

\section{References:}

1. Кашуба-Вольвач О. Українська академія мистецтва. Історія заснування (березень-грудень 1917). Хронологія подій, 2014. Київ : Фенікс. 224 с.

2. Воронюк В. Поезія і проза. Спогади. Бучач Львів - Вінніпег - Івано-Франківськ - Тернопіль, 2001. KH. III. 80 c.

3. Шмагало Р.Т. Мистецька освіта в Україні середини XIX - середини XX століття : структурування, методологія, художні позиції : монографія. Львів : Українські технології, 2005. 528 с.

4. Русакова Л. Художня освіта в Україні другої половини XIX - початку XX століття : історія та педагогічні пошуки. Проблеми підготовки сучасного вчителя. 2014. № 9 (2). С. 279-285.

5. Білокінь С. Перспективи дослідження мистецької спадщини Георгія Нарбута. Образотворче мистецтво. 1986. № 3. С. 16-18.

6. Дудник І. Від книжки до гривні. Український стиль Георгія Нарбута. Історична правда, 2011. URL: http://istpravda.com.ua/ articles/2011/08/26/53367.

7. Белецкий П.О. Георгий Иванович Нарбут. Ленинград : Искусство, 1985. 240 с. 
8. Ковпаненко Н. Нарбут Георгій Іванович. Видатні діячі науки і культури Києва в історико-краєзнавчому русі України : біографічний довідник. Київ : Інститут історії України НАН України, 2005. Ч. 2. С. 76-83.

9. Старченко В.І. Вплив народного малярства на творчість професійних митців України XIX - початку XX століття. Роль украиноведения в воспитании национального сознания и достоинства новой генерации украинцев : материалы Всеукраинской научно-практической интернет-конференции, г. Днепропетровск 14-15 ноября 2013 г. Дніпропетровськ, 2013. С. 17-20.

10.Дмитренко Н. Художня династія Кричевських. Україна молода. 2010, 6 серпня. С. 20-21.

11.Ковальчук О.В. Василь Григорович Кричевський. Митець і педагог (1873-1952) (до 130-річчя з дня народження). Народна творчість та етнографрія. 2003. № 1-2. C. 42-46.

12.Рубан-Кравченко В.В. Кричевські і українська художня культура XX століття : монографія : у 3 ч. Василь Кричевський. Київ : Криниця, 2004. 4. 1. 704 c.

13.Павловський В. Василь Григорович Кричевський. Життя і творчість : монографія. Нью-Йорк : Вільна Академія Наук у США, 1974. 316 c.

14.Соколюк Л. Михайло Бойчук та його школа. Харків : Савчук О.О. 2014. 488 с.

15.Кашуба-Вольвач О. Майстерня монументального живопису М. Бойчука у першоджерелах. Спогади Оксани Павленко і Василя Седляра. Образотворче мистецтво. 2008. № 4. С. 40-42; 2009. № 2. С. 24-29; 2009. № 3. C. 132-135.
16.Ковальчук О.В. Митець, педагог-новатор (до 120-річчя від дня народження М.Л. Бойчука). Українська академія мистецтва : дослідницькі та науково-методичні праці : зб. наук. праць Національної академії образотворчого мистецтва і архітектури, 2002. Вип. 9. С. 250-263

17.Ковпаненко Н. Бойчук Михайло Васильович. Видатні діячі науки і культури Києва в історико-краєзнавчому русі України : біографічний довідник. Київ : Інститут історії України НАН України, 2005. Ч. 1. С. 84-90.

18.Соколюк Л.Д. Михайло Бойчук та його концепція розвитку українського мистецтва (перша третина XX століття) : автореф. дис. ... д-ра мистецтвознавства : 17.00.05. Київ : Інститут мистецтвознавства, фольклористики та етнології імені М.Т. Рильського НАН України. 2004. 35 c.

19.Членова Л.Г. (вступна стаття) Олександр Мурашко. Альбом / автор-упорядник Л.Г. Членова. Київ : Мистецтво, 1980. С. 5-20.

20.ДобріянД.М.Виставковадіяльність Олександра Олександровича Мурашка (1898-1922 роки). Гілея : науковий вісник : збірник наукових праць, 2015. Вип. 93 (2). С. 122-125.

21. Ковальчук О.В. Історія живописного фракультету НАОМА і його роль у вихованні мистецьких кадрів та фооруванні національної живописної школиУкраїни 1917-1941 років:автореф.дис.... канд. Мистецтвознавства : 17.00.05. Київ : Національна академія образотворчого мистецтва і архітектури, 2003. 22 с.

22.Жбанкова О. Абрам Маневич. Живопис. Київ : Дух і літера, 2003. 33 с.

23.Лагутенко О. Всевладність Краси. Графіка та живопис Михайла Жука. Київ : Галерея НЮ APT, 2011. 144 c.

Бойченко М. А., Никифоров А. М. Дослідження життєвого та творчого шляху фундаторів Української академії мистецтв сучасними науковцями: педагогічний нарис

Статтю присвячено стану дослідженості життєтворчості засновників першої вищої художньої школи України упрацях сучасних науковців. Метою дослідженняєвивчення внескухудожників-педагогівзасновників першої Української академії мистецтв у становлення та розвиток національної художньої освіти в Україні початку XX столітmя, висвітленого в сучасних наукових розвідках. З'ясовано, що з ініціативи творчої еліти Києва за підтримки Центральної Ради й особисто Голови Центральної Ради М. Грушевського 18 грудня 1917 року було створено Українську академію мистецтв.

Установлено, що до профресорсько-викладацького складу новоствореного закладу вищої мистецької освіти було зараховано провідних художників, а саме: М. Бойчука, М. Бурачека, М. Жука, В. Кричевського, Ф. Кричевського, А. Маневича, О. Мурашка, Г. Нарбута.

Констатовано, що першим ректором Української академії мистецтв було обрано Василя Григоровича Кричевського (1873-1952), який викладав такі навчальні дисципліни, як: «Народне мистецтво», "Орнамент», "Архітектура», "Композиція». Зазначено, що першим діючим ректором академії (1917-1919) був Федір Григорович Кричевський (1896-1947), який очолював майстерню станкового живопису. Установлено, що керівником графічної майстерні було призначено Георгія Івановича Нарбута (1886-1920); Михайло Львович Бойчук (1882-1937) викладав навчальні дисципліни «Фреска» і «Мозаїка»; Олександр Олександрович Мурашко (1875-1919) був очільником навчальної майстерні курсу «Жанровий живопис»; Микола Григорович Бурачек (1871-1942) та Абрам Аншелович Маневич (1881-1942) викладали дисципліну «Пейзаж»; Михайло Іванович Жук (1883-1964) очолював майстерню портретного живопису. 
Показано, що творча та педагогічна діяльність фундаторів вищої мистецької школи України базувалася на дослідженні й використанні елементів традиційного українського мистецтва в поєднанні з новітніми європейськими тенденціями в розвиткові мистецтва й освіти.

Зроблено висновки, що заснована в 1917 році Українська академія мистецтв дала можливість митиям-україниям здобувати професійну художню освіту на Батьківщині, забезпечила високий рівень фрахової підготовки художніх кадрів та заклала підвалини розвитку вітчизняної педагогіки в галузі образотворчого мистецтва.

Ключові слова: становлення вищої художньої освіти в Україні, засновники першої Української академії мистецтв. 